\title{
Márgenes insurrectos
}

\section{Insurrect Margins}

\section{Resumen}

Este artículo propone una mirada al concepto de cuerpo, el cual es un protagonista privilegiado que aparece siempre en la escritura de Eltit como recorte, siempre fragmentario; cuerpo sufriente que sin embargo se desborda, se acomoda, se exalta y consigue hacerse de un espacio. Uno casi siempre marginal, sustituto, algún paisaje recién adquirido tras la expulsión; por eso los suyos suelen ser sujetos en tránsito, expropiados de su espacio original y hasta de sus nombres o su identidad.

Palabras claves

cuerpo, marginalidad, Diamela Eltit, identidad

\begin{abstract}
This article proposes a look at the concept of the body, which is a privileged protagonist that always appears in Eltit's writing as a cut-out, always fragmentary; a suffering body that nevertheless overflows, accommodates itself, exalts itself and manages to get a space. One almost always marginal, substitute, some landscape recently acquired after the expulsion; for that reason theirs usually are subjects in transit, expropriated of their original space and even of their names or their identity.
\end{abstract}

Keywords Body, Margianlity, Diamela Eltit, Identity 
Entrañable de algún oscuro modo, el proyecto literario de Diamela Eltit pasa, desde sus primeras señales, por cierta cercanía al cuerpo, sus humores, su sangre. Un cuerpo activo no solo intelectualmente, sino también en tanto biología, puede percibirse incluso en sus ensayos, lo mismo que en proyectos colectivos en que tomara parte la autora chilena. Valga mencionar apenas su novela El cuarto mundo - buena parte de cuya anécdota transcurre en el interior de un cuerpo (la madre) - , su ensayo sobre las fotografías de Paz Errázuriz en El infarto del alma y la consiguiente recuperación de ciertos fragmentos del cuerpo social que, de lo contrario, permanecerían ocultos, separados, confinados; su comentario de Pata de perro, de Carlos Droguett, o de aquellas otras imágenes de Errázuriz, "Baños colectivos de mujeres asiladas en el hospital psiquiátrico Philippe Pinel”. Los cuerpos, para Eltit, no son solo anatomía; en su dimensión social los describe como perseverantes cuerpos populares, marginados, excluidos de la narrativa imperante y de la imagen de un Chile homogéneo y feliz tras el fin de la dictadura; imborrables:

más allá de las expectativas sociales que se albergaban en relación al retorno a la democracia, persiste hoy, con una claridad indesmentible, el acoso y la discriminación hacia los cuerpos populares que solo existen en la medida en que cumplan con un doble estándar: fuerza de trabajo y sujetos consumidores a un crédito perpetuo, provocando así nuevas formas de controles y — despolitización mediante- la inoculación programática del consumo y la deuda.

El sujeto popular, figura central y privilegiada del programa político de Salvador Allende, ahora deambula por el imaginario social solo como sujeto de la delincuencia, como un actor cruel y peligroso gracias a una tecnología múltiple que, frente a la desigualdad y a la ausencia de programas reales para conseguir una mayor paridad social, recarga 
(recubre) a las figuras de una violencia que está incubada en el interior del propio sistema. ${ }^{1}$

El cuerpo, protagonista privilegiado, aparece siempre en la escritura de Eltit como recorte, siempre fragmentario; cuerpo sufriente que sin embargo se desborda, se acomoda, se exalta y consigue hacerse de un espacio. Uno casi siempre marginal, sustituto, algún paisaje recién adquirido tras la expulsión; por eso los suyos suelen ser sujetos en tránsito, expropiados de su espacio original y hasta de sus nombres o su identidad. Habría que pensar tales metáforas de cuerpos desplazados como señal de la condición del sujeto durante la dictadura. Tal desplazamiento, muchas veces huida y otras tantas prisión, fue lugar obligado de la izquierda chilena mientras el país estuvo tomado por la fuerza, ocupado por la sevicia de los militares. El sueño de las Grandes Alamedas para el pueblo se vio de repente clausurado; el sujeto popular fue empujado a los bordes, a los resquicios. La narrativa de Eltit se apropia de esos espacios laterales, fronterizos, donde pervive en permanente crisis el sujeto popular.

La primera novela de Eltit es, hay que decirlo pronto, un libro perturbador. Texto híbrido en muchos sentidos, imbricado como está con el presente de su escritura, Lumpérica (1983) irrumpió en el panorama literario como una propuesta equívoca, inasible; múltiple, en fin. Antes de ser publicada por Las Ediciones del Ornitorrinco — un proyecto que apostaba, en medio de tanta muerte, por defender la vida (según rezaba su página legal: “En un perdido rincón del planeta los ornitorrincos se extinguen. Con seguridad, no hay en toda la Tierra seres que luchen con más empeño por sobrevivir en ella")—, Lumpérica tuvo una breve aparición pública. Por aquellos años, como es de sobra conocido, Diamela Eltit integraba, con Lotty Rosenfeld, Juan Castillo, Fernando Balcells y Raúl Zurita, el Colectivo Acciones de Arte (CADA), un grupo de jóvenes que intentaba pensar la realidad

1 "Los bordes de la letra" (palabras de apertura de la Semana de Autora que le dedicara a Eltit la Casa de las Américas en La Habana en noviembre de 2002), Casa de las Américas, núm. 230 y "Se deben a sus circunstancias", en Diamela Eltit, Signos vitales. Escritos sobre literatura, arte y politica. 
para "intervenirla", para "ocuparla" con acciones públicas que hicieran reflexionar a sus espectadores acerca de las condiciones de vida, las relaciones sociales y el sentido del arte (Neustadt, CADA día).

Aunque tildados sucesivamente de crípticos, elitistas e ininteligibles, los gestos del CADA pueden leerse como señalamientos de la disfunción social permanente instalada por la dictadura pinochetista tras el golpe del 11 de septiembre de 1973. Prescindir del CADA resulta imposible al enfrentar Lumpérica; texto performático, gestual, toda su anécdota se narra en el tono con el cual podría describirse cierta actuación ante un espectador informado. Algunos apartados, los nombrados "ensayo general" o "escenas múltiples de caídas", colaboran en la percepción del relato como el libreto de una acción a medio camino entre la plástica y lo teatral. Los actos mismos de la protagonista sugieren la escenificación. Y es que Lumpérica, antes que libro, fue performance. Cierta noche ya célebre, Diamela Eltit leyó un fragmento de la novela en un prostíbulo de una zona popular de Santiago. Las fotos de ese día - de la serie "Zonas de dolor" (1981), de Lotty Rosenfeld — la muestran en un salón modesto, flanqueada por un pequeño grupo de espectadores, junto a una grabadora que presumiblemente registra la levedad del instante para el futuro ("Diamela Eltit, lectura en prostíbulo, calle Maipú"). En aquella velada, cuando Diamela leyó un fragmento de Lumpérica como una letanía frente a clientes y empleadas, no deja de intrigarnos la suspensión de la intimidad por la extraña intervención de esa voz enfáticamente chilena como diría ella de alguno de sus personajes - sin acompañamiento gestual. Hay otras fotos y grabaciones. En una de ellas puede verse a Diamela, cepillo en mano, junto a un cubo de agua, agachada en una acera solitaria, fregando el suelo ("Diamela Eltit, lavado de vereda en sector prostibulario, calle Maipú"). ${ }^{2}$ En otra más, portada de la primera edición de la novela, aparecen, reflejadas en la mugrosa pared de algún oscuro rincón santiaguino (quizás la misma calle, o una muy similar

${ }^{2}$ En María Inés Lagos, (Ed). Creación y resistencia: la narrativa de Diamela Eltit, 1983-1998. Agradezco a Mónica Barrientos el conocimiento de estas grabaciones y que me hiciera notar cómo alguna de las personas asistentes pregunta quién pagará la electricidad que están usando los equipos de filmación (la urgencia económica frente al gesto de arte, también un testimonio). 
a la del prostíbulo devenido sitio de arte) dos imágenes o, mejor, una imagen repetida: la proyección del rostro de Diamela, mirando seria y fijamente al frente, al espectador, a cualquier paseante desprevenido; la calle, como en Lumpérica, está vacía.

Aunque pueda parecerlo, esta no ha sido una vana disquisición. El aparente desvío soporta una de las claves de la novela. Lumpérica puede leerse como el guion de alguna de aquellas performances inesperadas en las cuales pretendían los miembros del CADA involucrar a la ciudadanía. La novela, "muy hábilmente, desconstruye el concepto de autenticidad y borra las líneas de oposición entre lo posado y lo auténtico, lo construido y lo esencial” (Klein 133). Eso haría más coherente - aunque la coherencia, como no sea la ética, es una palabra que se antoja ajena a la propuesta formal de Eltit - la presencia inesperada, incluso sorpresiva, de otra foto tomada por Rosenfeld, inserta en la sección "Ensayo general". Esta vez Diamela mira fijamente a la cámara, del mismo modo reconcentrado, pero aquí se entrevé además su cuerpo. Casi toda la figura está difuminada: su rostro se percibe apenas, los bordes de su cuerpo desaparecen en la oscuridad circundante; solo sus manos, sus brazos extendidos al frente, sobre sus rodillas, pueden verse con toda claridad: están vendados, con alguna imprecisa huella oscura en las gasas y la lóbrega sugerencia de un cuerpo maltrecho, herido, quemado, quién sabe si mutilado como su propia imagen. Como ha dicho Eugenia Brito, "la novela propone la ampliación del soporte lenguaje al cuerpo mismo, fotografiado y ocupado como material de trabajo, como un código más entre otros subcódigos, que son tomados, usados y desechados" (Brito 111).

El cuerpo femenino, tradicionalmente violado, violentado por los poderes del patriarcado, intervenido por la ausencia de derechos políticos iguales y por el mercado, que lo constriñe, lo coarta, lo rehace y lo pone en venta, territorio de inscripciones e incisiones del poder, botín de guerras y conquistas, se erige aquí como espacio de resistencia. L. Iluminada, la protagonista, es una mujer de quien solo conocemos una breve actuación. En un despoblado parque de Santiago pasa una noche consumiendo su tiempo en gestos inexplicables, acciones sin sentido. L. 
Iluminada carece de otro nombre salvo este, el de su condición momentánea, alumbrada como está por un inútil anuncio lumínico, encendido para nadie en las solitarias noches de una ciudad que intuimos vacía por la prohibición de la vida, el toque de queda, sugerido apenas por la ausencia total de transeúntes.

El nombre de L., otras veces llamada Lumpérica, ha sido leído, quién sabe si por evidencia de libros posteriores de Eltit (e. g. El cuarto mundo), como la conjunción de Lumpen y América, la América lumpen. Otra versión unifica lumpen e histérica, en provocadora cercanía a aquella tesis — creo recordar que de Emilce Dío Bleichmar - sobre el feminismo espontáneo de la histeria: prófuga permanente de la disciplina y el orden patriarcales, la histérica se resiste a la dominación, pues su existir irregular, impredecible y desordenado dinamita las ansias ajenas de control y sometimiento. Y lo mismo L. Iluminada, cuyo nombre destaca lo transitorio de su identidad siempre sospechosa por lo inesperado e incoherente de su conducta: de la abulia a la masturbación y de ahí a la autoagresión. Un cuerpo, el suyo, que no puede tomarse, no puede ser aprehendido real o simbólicamente; esa insignificante mujer vestida de gris está todo el tiempo gestionando significados, significados ignotos, imaginarios, remotos; ninguno se confirma. Lo que vale es la acción, el movimiento.

Metáfora de la nación, según Nelly Richard, "el cuerpo-mascarada de Lumpérica conjugó historia e histeria dislocándose en las rupturas ortográficas de la palabra-síntoma" (45). Al ubicarse en un parque público, el cuerpo femenino circula en la escena ciudadana, se define como cuerpo político, intencionalmente alejado del espacio doméstico. Increpa el orden establecido, la prohibición que desacata, pero enfrenta también la mansedumbre de tantas protagonistas de relatos previos, recluidas casi siempre en escenarios asfixiantes, opresivos, clausurados o, en el mejor de los casos, imaginados: compárese la inmovilidad de la amortajada de Bombal y la movilidad excesiva, en apariencia carente de sentido, de L. Iluminada. Aquí no se subraya el ambiente opresivo en que la acción transcurre, simplemente se desliza alguna indicación discreta: circulan en la noche patrullas policiales; no hay un solo despistado que vaya al parque a disfrutar el atardecer, el 
canto de los pájaros; nadie habla en la novela, salvo quienes escenifican un interrogatorio policial. A los mundos cerrados, imaginarios, casi siempre silenciosos de sus predecesoras, Eltit opone una escena pública fracturada, más realista, donde una mujer también silenciosa ejecuta su sorprendente performance en medio de una ciudad muerta o secuestrada, inerme y abandonada, adueñándose de las calles despobladas en la madrugada.

La expropiación a la ciudadanía de sus espacios de acción habituales es una de las más eficaces y frecuentes estrategias de la dominación. Con sus escenarios escamoteados, la ejecución de cada gesto resistente parece caer en el vacío, son gestos desajustados, inútiles. La apropiación — del espacio público, de su cuerpoemprendida por L. Iluminada califica, en su acumulación desconcertante, en su exceso de sentido nunca explicado, en su aparente futilidad, como acto de valiente resistencia; una resistencia que es pura política corporal: el cuerpo femenino se resiste no ya a ser constreñido a un espacio mínimo, el de la soledad, sino también a la docilidad, la belleza o la productividad (Olea 91): Iluminada se deshace a tijeretazos de su pelo, escenifica orgasmos reales o imaginarios para su público el lumperío, que asiste a la escena amedrentado por el frío, la lluvia, el hambre, sus propios impulsos-; esa energía inútilmente gastada, ese gasto improductivo solo por placer, da vida a un cuerpo insurrecto que, en su ¿libre? circulación por la ciudad tomada, se anuncia único dueño de sí. Circulación en libertad que va a constreñirse cada vez que el "luminoso" - un anuncio comercial, un reflector de vigilancia - se encienda sobre ella y le otorgue una identidad para introducir de nuevo el tema del control, pero en tono paródico: ya no hay ciudadanos, solo objetos en venta. Los pobladores nocturnos del parque donde transcurre casi toda la acción son gente sin rostro, deshechos, excrecencias, han sido convocados para adquirir una identidad, pero, si nos fijamos en L. Iluminada, su identidad depende de un leve gesto, su nombre mismo es transitorio: cuando no permanece al alcance del letrero lumínico ya no está iluminada, ya no es, y lo mismo el resto de los pálidos hambreados. L. Iluminada podría ser también una metáfora de la escritora 
frente a la tradición literaria, su deseo de explorar en total libertad todas las herencias, cada opción de estilo:

Pensaba, dice Eltit, cómo generar la máxima resistencia, no tanto al lector, sino con mi historia. Estaba pensando en la narrativa chilena. [...] En realidad yo soy muy literaria [...] Ese es mi mal. Yo siempre pienso en textos más que en gente [...]. Entonces en ese momento quería hacer [...] un texto bien consistente. Claro, estaba yo cuestionándome hasta el libro como institución. Todo, todo me estaba cuestionando. (Morales 144)

Como el cuerpo de L. Iluminada, alumbrado y oculto intermitentemente, el texto de la novela se organiza en los rituales del parque o el interrogatorio y se desarma en las inserciones reflexivas de una voz narradora que no solo desarticula la linealidad del discurso, sino también la grafía misma de las palabras, e incluye arcaísmos y citas ajenas. Es evidente, me parece, el nexo entre este tipo de escritura y las intervenciones practicadas por el CADA. En un lenguaje críptico para algunos, aquellos jóvenes explicaban sus acciones en textos —escritos casi siempre por Raúl Zurita o Diamela - más o menos oscuros. Textos que, en palabras de la propia Eltit: "hablaban de una vida mejor, de la posibilidad de una vida mejor. Y no se podía ir más allá. Era un lenguaje cifrado, donde todo el saber había que verlo entre líneas y entre líneas se hablaba, digamos, una cuestión antidictatorial" (Morales 163). ¿Estrategia de sobrevivencia? ¿Predilección por las metáforas? No solo; más bien la pretensión de politizar el arte y la escritura, sin rebajarlas, aun cuando sus gestos fueran casi siempre públicos e involucraran a gran número de espectadores. Lo visual ha sido una arista decisiva del trabajo de Eltit. Su apego a la imagen puede documentarse también en El Padre Mío —elaboración de una entrevista grabada a un loco santiaguino - o El infarto del alma —el testimonio gráfico de Paz Errázuriz acompañado por textos de Diamela ya mencionado - donde volverán a aparecer esos sujetos descentrados, a veces abúlicos, a quienes el poder no puede someter, pues ya habitan otro mundo. 
Multiforme, compleja, la primera novela de Eltit estimula la interpretación creativa y nos descubre una productividad de sentido que está, según su autora, "anclada en el rigor apasionado de continuar pensando lo literario en términos de un oficio acotado, y rebatir así la expectativa espectacularizante que promueve el libre mercado cultural" (Eltit "Los bordes de la letra" 110). Fragmentaria, con acotaciones indicadoras de un uso espectacular del relato - guion de cine, libreto teatral—Lumpérica es también un atrevido documento experimental. De ahí que no nos sorprenda del todo asistir a la presencia de esas dos caras gemelas de Diamela Eltit sobre una vieja pared lejana en la portada de aquella primera edición, ni advertir los vendajes que, en su otra foto, parecen ocultar cortes idénticos a los descritos en el cuerpo de L. Iluminada.

El trabajo con el espacio urbano acontece de modo progresivo. De la plaza pública en Lumpérica se pasa a otras representaciones de la ciudad más resistentes, por decirlo de algún modo, a una interpretación llana. En El cuarto mundo (1988) casi toda la acción transcurre dentro del útero de la madre que alberga a los gemelos, y luego, en la casa donde viven. Las salidas al espacio público denotan el descubrimiento del deseo, del tráfico no únicamente de dinero, sino también sexual:

Nuestra salida al exterior [relata uno de los personajes] fue verdaderamente estremecedora. La ciudad, tibiamente sórdida, nos motivó a todo tipo de apetencias y activó nuestras fantasías heredadas de mi madre. Se podía palpar en el espesor ciudadano el tráfico libidinal que unía el crimen y la venta. Los bellos torsos desnudos de los jóvenes sudacas semejaban esculturas móviles recorriendo las aceras. En ese breve recorrido nuestros ojos caían en una bacanal descontrolada. ("Tres novelas" 173)

Avanzando en la fusión entre anatomía humana y geografía urbana, el final de la novela propone una devastación total de la ciudad por la venta también total de los cuerpos que otrora la habitaban. La gente, sus campos, sus cosechas, todo se 
vende. Esta novela, imagen del progreso devastador, metáfora del proceso inacabado de conquista y colonización de América, de su entrada forzosa en el capitalismo, extiende la transacción permanente en la ciudad al cuerpo de sus habitantes. He aquí el apocalíptico final:

La ciudad colapsada es ya una ficción nominal. Solo el nombre de la ciudad permanece, porque todo lo demás ya se ha vendido en el amplio mercado. En la anarquía de la costumbre por la venta se ejecutan los últimos movimientos a viva voz, voceando la venta al vacío. [...] Lejos, en una casa abandonada a la fraternidad, entre un 7 y un 8 de abril, diamela eltit, asistida por su hermano mellizo, da a luz una niña. La niña sudaca irá a la venta. (173)

Curioso modo de escenificar la extensión sin límites del mercado. Igualmente infinito, el territorio de la violencia ocupa mucho más que el espacio urbano en Vaca sagrada (1991), cuyos protagonistas se ven permanentemente increpados por una realidad oscura, opresiva:

En ese momento la sensación de muerte se acababa de instalar en la ciudad. Manuel no dio ninguna señal de acercamiento hasta que me enteré de que había sido detenido en el sur junto con toda su familia. Aun cuando temí que fuera asesinado, reconozco que intenté erradicar ese peligro de mi mente. Tengo una marcada inclinación a perderme en cualquier caos y el desorden que atravesaba ese tiempo no me dejó la menor alternativa.

Desarmada, confundida, dejé atrás toda mi historia para reiniciar el aprendizaje del mapa de la ciudad, de los rostros. La antigua crisis con mi existencia perdió todo su aliciente. Convulsa, mis dudas se remitían, en esos días, al peligro del afuera, a la noche, al evidente riesgo de las noches. 
La voz de esta mujer casi siempre sangrante (la sangre menstrual, abundantísima, la hace más deseada por su amante) escenifica la imposibilidad del placer, con la consiguiente deshumanización progresiva, en tiempos de violencia: “Cuanto deseé a Manuel ese día. Mi cuerpo estaba caliente y mi única posibilidad con el placer permanecía recluida en algún sitio clandestino del sur" (42). Aquí, sin embargo, la sangre aparece como defensa vital, "Manuel estaba detenido en el Sur y mi sangre conseguía detener su muerte por una noche” (51), dice también. El cuerpo, pues, se opone a la borradura de una vida citadina donde el desempleo, la violencia, la ausencia del placer y la carnalidad (cuando el cuerpo crece, literalmente, la mujer no logra recorrer la ciudad) lo increpan constantemente. Entonces afloran la simulación, el disfraz, el maquillaje, la mentira. Mentir es otra de las cualidades bien mostradas; la voz narradora debe mentir para sobrevivir, fingir para transitar el espacio colectivo; ya había advertido "Duermo, sueño, miento mucho [...] Sangro, miento mucho" (11). La mentira va a ser su única garantía de sobrevivencia en ese mundo hostil donde la violencia social se conjuga con la violencia cotidiana en la relación entre los amantes, en una duplicación más que frecuente en la narrativa de Eltit. Sobre los múltiples niveles de la ficción en esta novela podría decirse más, y más aún de los cruzamientos entre historia y ficción, del uso del cuerpo — ese cuerpo sangrante, mentiroso- como metáfora social, leit motiv en la creación literaria de su autora, quien recrea el espacio urbano otra vez en Los vigilantes, de 1994, desde la ausencia. Una ausencia opresiva, claro, porque la ciudad es el escenario de lo ignoto, de lo narrado desde la persistencia de una idea: todo es vigilancia y persecución. Una madre y su hijo viven en total reclusión (aquí de nuevo la casa reproduce en su mínima geografía el trazado urbano) y sus cartas al padre ausente (ligado de algún modo oscuro a las fuerzas represivas) reclaman una atención nunca conseguida.

Santiago de Chile, escenario frecuente en sus ficciones, es apenas el paisaje de tránsito, en Mano de obra (2002), entre dos espacios cerrados: el supermercado donde dejan sus vidas los protagonistas y la casa donde conviven para compartir gastos. Entre ambos transcurre, silenciosa, la vida citadina. Anonadados por la 
explotación de la cual son objetos casi siempre inermes, lacerados, arrumbados unos sobre otros en un mínimo espacio de supervivencia, los trabajadores del supermercado van construyendo alianzas más o menos solventes que terminan dando paso al enfrentamiento o la servidumbre. Cuerpos macilentos, mal alimentados, incluso mutilados real o simbólicamente (una empleada pierde un dedo mientras trocea pollos; otro debe disfrazarse de San José y permanecer todo el día en un pesebre de cartón); esos cuerpos, decía, sucios, malolientes, envejecidos y aletargados, se superponen, en la primera parte de la novela — no por gusto titulada "El despertar de los trabajadores, Iquique, 1911”-, a la tradición combativa del movimiento obrero chileno, aludida en los títulos de cada capítulo de esa primera parte, con titulares o nombres de periódicos obreros, más el lugar y año de publicación (“Autonomía y solidaridad, Santiago, 1924”, "El proletario, Tocopilla, 1904”, “Acción directa, Santiago, 1920”, “El obrero gráfico, Valparaíso, 1926", son algunos de ellos). El contraste con la segunda parte — "Puro Chile, Santiago, 1970"- se refuerza con la comprobación de una humanidad cada vez más declinante. ${ }^{3}$ Aquí los títulos son apenas frases explicativas de la anécdota: "Sonia lloró en el baño", "Sonia se cortó un dedo" o "A Enrique casi le da un ataque". Contado en un lenguaje muy cercano al habla popular santiaguina, este segmento da cuenta, también a nivel de la lengua, de la contracción de la acción social, de ese repliegue hacia lo íntimo e individual y finalmente, hacia la inacción y la sumisión.

En otro escenario transcurre Los trabajadores de la muerte (1998): un lugar límite no ya del espacio citadino, sino de lo humano propiamente dicho. En los márgenes de la ciudad, en una taberna de paredes cariadas, una niña manca, acompañada de dos inválidos, provoca de algún modo ignoto la furia de los bebedores, a quienes impone también cierto respeto igualmente inexplicable. La taberna, justo a las puertas de un albergue de menesterosos, es la portada de una ciudad incomprensible, habitada por esos personajes sin nombre, una burla casi a

${ }^{3}$ Puro Chile, diario afín al gobierno de la Unidad Popular, fue clausurado por la dictadura militar después del golpe de estado contra el gobierno de Salvador Allende. 
la ilusión desarrollista tan explotada en el contexto chileno. Para terminar, la novela da cuenta de esa contradicción:

Atardece, Santiago se disloca, muta. Por un altoparlante se escucha la última promoción de un candidato a un sitial político que apela a su carisma con el pueblo. Santiago se disloca. Los grandes avisos desplegados por la cuadra alertan a los ciudadanos para que se preparen a combatir la expansión de las epidemias. [...] La niña del brazo mutilado permanece custodiando la entrada del paseo principal. Por su cara impávida, por la altanera recurrencia de su pose, se desliza la potencia con la que encubre el legendario enigma. (205)

Los cuerpos mutilados, los mendigos, ocupan las calles; la ciudad experimenta una contracción hacia sus propios márgenes. Tal eliminación progresiva del espacio urbano alcanza un momentáneo colofón en Jamás el fuego nunca (2007). Allí un hombre y una mujer pasan el tiempo acomodándose y reacomodándose en una cama de sábanas gastadas, bastante maltrecha, en una habitación de paredes despintadas. Imagen de un fracaso, esta pareja compartió un pasado brevemente glorioso, el de la militancia clandestina. Sin embargo, su entrega política total determinó el futuro de pesadumbre en que se afirma su presente: un hijo muerto por falta de atención médica, pues acudir al hospital sería revelarse a las autoridades. ${ }^{4}$ El cuerpo, siempre espacio político en los textos de Eltit, se politiza doblemente aquí: cada órgano, cada célula, establece un paralelo con las células de la organización clandestina. Para esos cuerpos que siguen viviendo en la clandestinidad de la pobreza y el abandono, en la infelicidad de la

${ }^{4}$ Eltit reescribe sobriamente la dramática situación donde el compromiso político de los padres deriva hacia la muerte inevitable del hijo, relatada ya con hondura tremenda por el mexicano José Revueltas en Los días terrenales (1949). Si en Revueltas la acción política era el presente (y la habitación donde muere la niña, simbólicamente llamada Bandera, está repleta de consignas y carteles), la escena imaginada por Eltit transcurre en el futuro: la muerte ya ocurrió, la lucha se perdió, la vejez y el dolor corporal se imponen al sueño de la acción, ahora ceñida a la mera sobrevivencia. 
derrota, la ciudad es un espacio fantasmagórico, de raudas apariciones utilitarias (es preciso salir, ganar algo de dinero y regresar rápido al refugio).

El cruce entre biología e historia, usual en los textos ficcionales y ensayísticos de Diamela Eltit, toma cuerpo — nunca mejor dicho- en un paralelo inesperado. Las células de la organización clandestina semejan células biológicas; muertas unas, se revela la muerte de las otras, en una cita inesperada de Pedro Páramo. La densidad conceptual de Jamás el fuego nunca pone en escena nuevamente la corporeidad de lo político; la idea de la polis como espacio de interacción de los cuerpos, perceptible también en la idea de nombrar una colección de escritos varios como Signos vitales, en uno de cuyos comentarios, "Los estigmas del cuerpo", la autora se permite una reflexión de una profundidad y una desazón inusuales en otros contextos, clara demostración de los inesperados lazos que anuda insistentemente su lectura de los cuerpos en el espacio urbano que es, siempre con la inevitable remisión etimológica- un espacio político. ${ }^{5}$

Cuando presentábamos la edición cubana de Lumpérica, en la Feria del Libro de 2009, Diamela hizo énfasis en su permanente interés por trabajar con el fragmento. Jamás el fuego nunca ilustra con creces ese interés; los cuerpos, reducidos a su mínima expresión, no son más que extremidades u órganos, primero; un amasijo de dolores y padecimientos, después. Para el final de la novela, lo humano ha quedado acotado apenas en una existencia pura y fatalmente biológica: los cuerpos no son entonces otra cosa que células, mínimas células en trance de morir.

La escritura de Eltit puede leerse íntegramente como un ejercicio de corporeización de la letra. Lo corporal incluye, en su trabajo, desde el gesto y la prestancia de los cuerpos hasta el flujo sanguíneo y lo estrictamente celular. Pero esa cercanía con la carne y la sangre no hacen un discurso ficcional, de ningún

\footnotetext{
${ }^{5}$ Véase "Los estigmas del cuerpo" en Diamela Eltit, Signos vitales.
} 
modo concebido como asunto íntimo, como registro de humores y heridas más o menos visibles. El cuerpo en su narrativa adquiere un lugar central, es cierto, pero solo porque a través suyo se narran epopeyas más o menos públicas, más o menos ignoradas, más o menos eludidas por la historia oficial. Así, en Lumpérica el cuerpo de L. Iluminada es el suyo, claro está (el de una mujer itinerante, sin identidad fija, que circula incansablemente por la ciudad vedada a sus iguales); pero es también el cuerpo social, disminuido, sojuzgado con clasificaciones, con restricciones varias, con agresiones (incluso la tortura), todo como parte del paisaje urbano en tiempos de la dictadura militar. Pero el relato podría leerse llanamente como la historia de una deambulante y nada más. Es posible, sí, aunque para hacerlo debamos negar su esencia misma.

Tal compromiso con lo corporal y lo social ha venido estrechándose parejamente a medida que el trabajo de Diamela Eltit va entregando nuevas muestras. Ya su mentado ejercicio como integrante del CADA ponía el cuerpo en juego y, quizá también en peligro.

Otros textos suyos siguieron mostrando esa conciencia de lo carnal político, que parecería suscribir la eficaz sentencia de Kate Millet. Bajo tal invocación pareciera haberse escrito toda su obra, muy notable en el conjunto de autores latinoamericanos coetáneos, precisamente, por su tremenda originalidad y por su vínculo con una idea no solo del cuerpo y la sociedad, sino también de la literatura, mantenida, sin repetirse, por más de tres décadas. La centralidad del cuerpo en la historia social ha sido trabajada por Eltit de mil modos, y, como se ha visto aquí, sus novelas Por la patria (1986), El cuarto mundo (1988), Los trabajadores de la muerte (1998), Mano de obra (2002) y Jamás el fuego nunca (2007) han explorado la relación corporal de sus protagonistas con el paisaje urbano, con el tejido social del cual forman parte, a veces como pústulas, a veces como miembros en trance de amputación o muerte. La elaborada metáfora con que Eltit ha compuesto su narración de la realidad social chilena se ocupa no solo de la representación del cuerpo y sus enfermedades, carencias o avatares (el parto, la sangre menstrual, los "lazos de sangre" son materia común de sus escritos), sino del devenir histórico de 
esos cuerpos a veces aniquilados y a veces en pleno combate, en plena batalla por la recuperación de sí mismos; batalla, hay que decirlo, muchas veces perdida.

Sus ensayos refieren también a temas como la enfermedad y la salud y no es casual que dos de sus más conocidos títulos sean Emergencias: escritos sobre literatura, arte y política (2000) o, en una alusión mucho más clara: Signos vitales (2008). La propensión a estudiar la naturaleza social de las exclusiones más drásticas ha hecho también detenerse su pluma en el estudio y registro de las voces no escuchadas, recluidas, voces repetitivas o fantasiosas cuya realidad distinta, creada a partir de la palabra, no da únicamente una pista para entender el orden desordenado de sus experiencias vitales, sino el orden aparentemente eficiente de la sociedad exterior. Ahí están, para probarlo, los testimonios antes aludidos El Padre Mio (1989) y El infarto del alma (1994), donde recupera la voz de los dementes y da cuenta de sus obsesiones, de las numerosas intervenciones médicas a que han sido sometidos, no solo psiquiátricas (incluye, por ejemplo, la esterilización de mujeres dementes). Es importante recordar ahora El infarto del alma porque los personajes protagónicos de otra novela de Eltit, Impuesto a la carne (2010), hablan incansable, repetitiva, obsesivamente acerca del control de sus cuerpos y sus vidas por los médicos, por aquellos que saben qué es mejor, y a quienes esos saberes les otorgan el derecho a intervenir, medicar, trocear los cuerpos, si fuera preciso. El infarto del alma escribía también sobre (y contra) la reclusión, la pérdida de identidad - la mayoría de los enfermos son indigentes, algunos catalogados como N. N., es decir, sin nombre o familia conocidos- o la manipulación de los cuerpos por la medicina y la ley.

Eltit posee una formación teórica muy fuerte, que aflora en sus textos de la manera más inesperada. Leyendo El infarto... recordamos a Foucault, a Freud... pero también a Marx y a muchos otros. En aquel texto de acompañamiento para las fotos que hiciera Paz Errázuriz en el hospital psiquiátrico de Putaendo, un mundo otro, a solo dos horas de Santiago. Diamela relata cómo ambas fueron recibidas al llegar: 
como si ellos mismos no lo pudieran creer y más la besan y más la abrazan y a mí también me besan y me abrazan hombres y mujeres ante los cuales debo disimular la profunda conmoción que me provoca la precariedad de sus destinos. No sus rostros ni sus cuerpos, me refiero a nuestro común diferido destino.

¿Qué sería describir con palabras la visualidad muda de esas figuras deformadas por los fármacos, sus difíciles manías corporales, el brillo ávido de esos ojos que nos miran, nos traspasan y dejan entrever unas pupilas cuyo horizonte está bifurcado? ¿De qué vale insistir en que sus cuerpos transportan tantas señales sociales que cojean, se tuercen, se van peligrosamente para un lado, mientras deambulan regocijados al lado de Paz Errázuriz, ahora su parienta? (10)

La percepción de una huella social en las incisiones, heridas, torceduras y hematomas de esos cuerpos recluidos ¿para evitar la contaminación? podría considerarse un antecedente claro de la voz que se agita y demanda en muchas de sus novelas posteriores. Espacio vital, escenario social, el cuerpo en la narrativa de Diamela Eltit aparece una y otra vez comprometido de los modos más diversos: escenario casi único para los gemelos de El cuarto mundo (1988); herida permanentemente sangrante en Vaca sagrada (1991), a cuya protagonista le han amputado a su amante, desaparecido; objeto sucesivo del deseo y la explotación capitalista en Mano de obra (2002); en la autonomía de los cuerpos mutilados, mendicantes, malévolos, de Los trabajadores de la muerte (1998); o en la reproducción corporal (a nivel celular, lo he dicho antes) de las organizaciones políticas clandestinas durante la dictadura militar en Jamás el fuego nunca (2007).

Según reza la nota de contraportada, esta novela podría contarse así:

Un hospital. Hordas de médicos. Enfermeras que trafican sangre. Grupos de fans. Enfermos vaciados de sus órganos. Impuesto a la carne funciona como una metáfora nacional de los últimos doscientos años, en la que será 
posible reconocer algunos de los paisajes más sórdidos de nuestra historia. Una crónica marginal que registra el tránsito de dos almas anarquistas por un espacio opresor.

$[\ldots]$

Elemento fundante de la novelística de Diamela Eltit, el cuerpo, en esta oportunidad, se convierte en el escenario en el que se despliegan las certezas y fisuras propias de la relación entre una madre y una hija. La autora se embarca en una lectura orgánica de la figura materna, esta vez no en clave simbólica, sino como un ente corpóreo y vivo que habita, literalmente, las entrañas de toda hija. ${ }^{6}$

Hay en esta breve descripción dos menciones que debemos retener: la primera, el asunto de la metáfora nacional; la segunda, esa presencia orgánica y eterna de la madre en su hija. La idea de metaforizar la historia nacional es usual en la narrativa de Eltit, como se ha visto antes, y el asunto de los cuerpos fundidos en uno ya había aparecido también. Pero Impuesto a la carne, cuyo título alude a una obligación, a una deuda, funde estas constantes temáticas para expresar un devenir insatisfactorio. La voz narrativa, perteneciente a la hija, provee una vía para la lectura de esas vidas en clave histórica. La novela comienza así:

Nuestra gesta hospitalaria fue tan incomprendida que la esperanza de digitalizar una minúscula huella de nuestro recorrido (humano) nos parece una abierta ingenuidad. Hoy, cuando nuestro ímpetu orgánico terminó por fracasar, solo conseguimos legar ciertos fragmentos de lo que fueron nuestras vidas. La de mi madre y la mía. Moriremos de manera imperativa porque el hospital nos destruyó duplicando cada uno de los males.

Nos enfermó de muerte el hospital.

Nos encerró.

\footnotetext{
${ }^{6}$ Nota de contracubierta en Diamela Eltit, Impuesto a la carne. Editorial Planeta, 2010. Cito por esta edición.
} 
CATEDRal Tomada: Revista de crítica literaria latinoamericana / Journal of Latin American Literary Criticism Márgenes insurrectos

Nos mató.

La historia nos infligió una puñalada por la espalda. (9)

Una y otra vez la voz pregunta, “¿hace cuánto?, ¿unos doscientos años?”, para responderse enseguida, "sí, doscientos años”. El gesto repetido, la pervivencia de la misma situación durante dos siglos, da la primera señal. Madre e hija viven internadas en un hospital, acosadas por fanáticos de la medicina y por médicos que intervienen continuamente sus cuerpos. La metáfora nacional (esos doscientos años de legalidad de la nación chilena) se entrevera aquí con las políticas higienistas esgrimidas como argumento primero de la intervención del gobierno en la vida privada, en los gestos, comportamientos o adscripción sanguínea (en el caso de los indígenas) o en la capacidad de decidir quiénes están aptos y quiénes no para formar parte de la nación. La metáfora higiénica, la intervención en un cuerpo social enfermo, cuyas partes contaminadas habría que amputar, sería — por cierto- una de las imágenes favoritas del discurso de los gobiernos militares en el continente, y se equiparaba así a la salvación del país.

Hay también un dato nada desdeñable. El primer médico tiene una característica sobre la cual se insiste: es Blanco. Manuel Blanco Encalada fue el primer presidente de la República de Chile, electo en 1826. La alusión a la historia nacional no es gratuita, y a partir de entonces se hace permanente la higienización, medición y educación de esos cuerpos que terminan por ser intoxicados, lentamente desangrados y siempre vigilados. La rebelión, sin embargo, parece posible. Dice la protagonista sin nombre: "nosotras incitamos a nuestros órganos a una posición anarquista y así conseguimos imprimirles una dirección más radical a nuestros cuerpos" (15), y también dice:

Me aferré a mi madre de una forma que podría considerarse maníaca o excesivamente primitiva. Lo hice porque desde nuestro nacimiento (marcado por signos de una abierta rebeldía) estuvo claro que éramos dos seres o dos almas solas en el mundo. 
La patria o el país o el territorio o el hospital no fueron benignos con nosotras.

Mi madre (que ya era anarquista) se permitió disfrutar de un éxtasis prolongado cuando comprendió que éramos dos mujeres solas en el mundo. (18)

Estas dos mujeres, madre e hija, van delineándose como espacios de la nación, contradiciendo los planes de cada médico. A pesar de mediciones y remedios, la hija nacerá muy parecida a la madre: ambas son bajas, feas y aterradoramente comunes. Así, llega un médico tras otro para analizar, medir, medicar. Todos son altos, y cuando hay uno bajo, lo mismo que ellas, la estatura puede ser un tema a discutir: todos los médicos son altos (es decir, respetables). La hija, entonces, decide mentir y aceptar lo que llama las "fantasías nacionales de altura" de la madre, y la alusión a la historia chilena no se hace esperar: "Dos mujeres pequeñas que no íbamos a crecer en ningún sentido y cuyos órganos débiles nos convirtieron en una atracción turística para los médicos, uno y otro, un cabildo de médicos, una interminable junta de médicos, un parlamento médico. Sí, una nación o un país o una patria médica plagada de controles parciales..." (29-30). Hay una remisión a la historia, pues cabildo, junta y parlamento son tres modos de gobierno sucesivos: el cabildo inicial, la junta militar, el parlamento representativo. Tal es la historia que la hija quiere contar, en su peculiar cuerpo a cuerpo con la madre, que diría Cixous:

Mi programa es apelar a un escrito sin pretensiones, escalofriantemente sencillo, a un simple diario local o a una memoria que no se termine de comprender del todo y que, sin embargo, nos permita hacer un milímetro de historia.

Una gesta encabezada por nosotras, unas mujeres solas en el mundo. Dos ancianas que ya hemos cumplido ¿cuánto?, no sé, ¿doscientos años? Y que luchamos para que el terrible y hostil transcurso del tiempo nos garantice 
que en los próximos doscientos años que se avecinan van a empezar a circular nuestro legado.

No, me dice mi madre, nunca va a circular ni un pedacito de palabra. La nación o la patria o el país van a aplastar la revuelta de la sílaba. No. Ni en cuatrocientos años más, insiste mi madre. Ni siquiera en cuatrocientos.

Una vez más, la voz narrativa de Diamela Eltit ha tomado a su cargo el señalamiento de los excluidos de la historia, estas mujeres que vagan solas y asustadas por el hospital, que no cumplen el sueño de representar lo nacional: son bajas, son morenas — "Nos dicen: Negras curiches" (35)_, son parias. La madre, conservadora, más dócil, se niega a apoyar el desdén de la hija por los médicos:

Tendrías que ser tonta o retardada, me dice mi mamá, para profanar la burbuja histórica de la nación, del país o de la patria médica, así es que te repito, cállate la boca y déjalos en paz, que hagan lo que quieran, lo que se les antoje. Nosotras estamos aquí para permitir y hasta estimular que nos sigan tratando como subpacientes o subespecies, qué nos importa, dice mi mamá, mientras respira con una dificultad terminal adentro de mi pecho. $(35-36)$

Madre e hija mantienen el forcejeo perpetuo entre sumisión y resistencia; la muerte orgánica se equipara a la muerte civil; la parentela asustada y servil va muriéndose poco a poco, hasta dejarlas solas. Una con la otra. Nadie más que ellas y los médicos con su grupo de fans, que los sigue y aplaude sus acciones, por poco honorables que sean. Así, van transitando por varios niveles hasta reconocer su total prescindencia, siempre a merced de los médicos; pero también empiezan a reconocer su fortaleza, van recuperando su capacidad para enfrentarlos. La madre podría ser el territorio preexistente, o bien la historia patria, o la identidad misma de la nación chilena. Sin ella, la hija no podría vivir, es la hija quien deberá sufrir 
gestos lindantes con la tortura por parte de los médicos y recordar cuando la madre olvide. He aquí otra de las elaboraciones de la historia nacional llevadas al continuo parloteo de la hija hospitalizada:

Mi madre afirma que los médicos generales eran atentos y olvida senilmente que sus características opresoras sobre nosotras los volvían temibles, violentos. Se niega a aceptar mi madre que ellos no tenían escrúpulos porque prácticamente no nos examinaban y nos trataban con una violencia que no comprendo cómo ha podido disculpar.

Así son los generales.

[...] Cómo es posible, me pregunto alarmada, que mi madre memorice a cada uno de ellos como un servidor social de nuestra salud en circunstancias que ha sido un territorio, el de nuestra salud, duramente ganado. $[\ldots]$

Yo oscilo entre el miedo y la furia. (54)

Nótese ahora la equiparación histórica: los médicos generales son aludidos luego como "los generales". En ese paisaje equívoco, ellas sobreviven entregando su sangre al cuerpo de enfermeras, huyendo de los fans que las vigilan, haciéndose las bobas ante cualquier sospecha de sabiduría o rebelión. La hija quiere escribir su versión de la historia, la madre se niega, sabe que eso las condenaría. Cada vez que decide enfrentar la opresión hay un pacto de silencio. En ese país "que no devuelve el mar" (obvia referencia al conflicto por la salida al mar de Bolivia, tema permanente en la política chilena) hay cosas que no pueden decirse, y otras alcanzan a soportarse a duras penas:

No sé vivir sin experimentar el castigo de la patria o de la nación o del país. Este país que no devuelve el mar, que no devuelve el mar, que se traga, se traga las olas del mar, se traga el mar. Se traga todo y por eso en 
cada uno de estos años y en la percepción que me provocan las horas comprendo cómo funciona el castigo de la nación o de la patria.

El castigo interminable de un territorio que me saca sangre, me saca sangre, me saca sangre, me saca sangre. Que me saca sangre. (80)

Tanto modo equívoco de servir a la patria (o la nación, o el país), dándole sus sangres y sus órganos, donándolo todo para un fin desconocido o francamente reprobable terminará por convertir aquellos cuerpos, extasiados en su propia increíble sobrevivencia, los de madre e hija, en uno solo. Un único cuerpo que ya no es más el de ambas, ya no es más el cuerpo de la hija con la madre alojada en sus costillas, ya no. Finalmente, el cuerpo que da voz a la narración ha sobrevivido a los múltiples atentados médicos y a las celebraciones hueras, a la esperanza de intervenir en la escena pública al menos por un segundo, mientras, subido a la tarima de la celebración del bicentenario, dejaba su huella fugaz en imágenes digitales, en la televisión y los blogs que reportarían su aparición confusa y confundida. La identificación de la hija —a duras penas sobreviviente a múltiples intervenciones y cercenamientos, con el cuerpo repleto de cicatrices y expoliado, a punto de morir o volverse loca- con la historia nacional llega a su clímax. La madre se ha asentado en algún sitio en su interior, es un órgano más. Fundidas, ambas darán lo último por el bienestar de la nación. Sin embargo, sus cuerpos rebeldes serán la sede de la revuelta: "pronto iniciaremos la huelga de nuestros líquidos y el paro social de nuestras materias" (186), anuncia la hija, para concluir, casi enseguida, con su madre cantando un himno en su interior.

He intentado un recorrido a grandes trancos por ese argumento inesperado y sutilmente confuso. Ahora pareciera, ante este párrafo final, reafirmarse la impresión metafórica de esta anécdota a ratos inexplicable. La identificación frecuente entre esos cuerpos bicentenarios, expoliados, aniquilados y engañados con la nación chilena se actualiza una vez más con el señalamiento final. Las anarcobarrocas, como ellas mismas se llaman —en inevitable asociación con Auxilio y Socorro, las protagonistas de De donde son los cantantes, de Severo 
Sarduy, y su modo burlón de enfrentar la vida-, las delirantes pacientes de ese hospital que puede ser también un país, terminan ellas mismas "operadas, rotas, mal cosidas" y víctimas de una rebelión interna. También sus órganos se juntan para rebelarse, para fundar una comuna, para "protestar por el estado de su historia" (clínica, se entiende). No hay futuro para recomponer ese cuerpo gastado y sumamente maltratado que reconoce llegado el fin:

Ya es tarde para nosotras. El territorio puso en marcha un operativo para decretar la demolición y expatriación de nuestros cuerpos. Minas. Minerales. Nuestros huesos cupríferos serán molidos en la infernal máquina chancadora. El polvo cobre del último estadio de nuestros huesos terminará fertilizando el subsuelo de un remoto cementerio chino. (187)

Este final casi apocalíptico, como aquel irónicamente estremecedor de $E l$ cuarto mundo - "la niña sudaca irá a la venta"-, reconoce una imposibilidad: la supervivencia de la nación en un mundo dominado por el capital transnacional, cuya única razón es la ganancia. Por eso la identificación de sus cuerpos con el cobre, recurso indispensable de la economía chilena y catalizador de un movimiento obrero de fuerte presencia en la historia del país. La ironía constante en las situaciones descabelladas que primero imagina y luego naturaliza Diamela Eltit son el inicio mismo de la rebelión; la conciencia del ridículo es la causa movilizadora de su protagonista, esa conciencia alimenta su percepción de la historia fallida de una nación negada a reconocer sus faltas o a dar cobijo a todos sus hijos. Un cuerpo sobreviviente, cuerpo de mujer, contiene todas las heridas y toda la memoria, pero su voz — su proyecto de comuna anarquista — no ha podido escucharse en el espacio común. Cuando se funde con el suelo chileno y sus recursos naturales enfrenta un futuro al parecer ineluctable: la demolición, la desaparición. No sorprende, tratándose de una narradora con tan clara percepción de lo político, ese final que parece invocar otros tiempos de la historia chilena y reconoce, en la aniquilación total que conlleva la exclusión, la posibilidad de la 
muerte definitiva de esa mujer bicentenaria que bien podría ser la patria, la nación o el país, como ella misma, confusamente, ha venido proclamando.

Desde que alguien habló de "economía libidinal”, o Severo Sarduy propuso su teoría de que el barroco es dispendio, exceso, goce improductivo, resistencia a la norma, las economías son mucho más que número. Desde Lumpérica, la narrativa de Diamela Eltit ha venido elaborando una reflexión crítica, política, del entorno social chileno. Atraída por los más disímiles paisajes, sea el del espacio público durante la dictadura o los atajos marginales de un manicomio retratados por $\mathrm{Paz}$ Errázuriz; Eltit imagina cuerpos en ruinas, arrasados por la lucha política, casi detritus de una dedicación, de un ejercicio público, intervenidos por fuerzas médicas (la paranoia que sanciona la intervención desmedida, no solo en los cuerpos, sino en la práctica pública de los sujetos), por la pobreza o por el poder, instancias todas que desconocen y niegan la integridad corporal hasta sumirla en el despiece, sea quirúrgico o accidental.

Los cuerpos narrados por Eltit han sido previamente intervenidos, ocupados por fuerzas ajenas. En Fuerzas especiales (2013) la intervención es literal: los protagonistas habitan un bloque de viviendas sociales permanentemente custodiado e intervenido por la policía y sus perros, la policía y sus armas, la policía y sus golpes. Perros, armas, vigilancia y golpes son otros protagonistas de esta historia. Vivir en esos bloques de edificios multifamiliares casi abandonados, a medias despoblados, con parte de su gente sustraída por la actividad represiva de la policía, transitar por ellos, es poner a prueba cada día la propia capacidad de supervivencia. La vida anodina de la protagonista parece explicar su indiferencia: se limita a pasear por un espacio limitado entre el cíber y su casa, con una parada momentánea para comer un bocado roñoso. La paga, el dinero, es relevante en su paisaje; la joven narradora relata cómo se gana la vida: en un cubículo del cíber, mientras visita sitios virtuales, vende su cuerpo, dejándose ocupar por el cliente de turno. En ese entorno totalmente inhóspito, no tanto por la vacuidad estética de los bloques o por la baja calidad de los materiales y el diseño, sino por la permanente amenaza de la policía, transcurre su irrespirable vida, en un apartamento de treinta metros cuadrados 
donde convive con sus padres y su hermana. Faltan, en el conteo familiar inicial, algunos miembros: los hijos de su hermana y sus propios hermanos, cuyo destino solo podemos intuir (¿fueron raptados para vender sus órganos? ¿se fugaron de casa? ¿los asesinó la policía? ¿fueron vendidos en adopción? ¿se los llevaron los servicios sociales?). No hay modo de saberlo, y tampoco importa demasiado. En el asfixiante registro de iniquidades cotidianas esa ausencia es solo una herida más; allí donde los personajes deben soportar apenas la vida, desaparecer, no estar, parece ser incluso preferible al desgaste deslucido del día a día.

Los cuerpos compendian cicatrices, dolores, penas, el anhelo de borrarse de una vez, de hacerse invisibles, de ocultarse de las miradas siempre voraces de la policía. En esa huida permanente aparecen, como fogonazos, algunas explicaciones de las heridas visibles: al padre le hundieron las costillas; azotaron a la hermana; sus amigos tienen marcas infligidas por la violencia de la fuerza pública. Es por eso que el espacio virtual ofrece un paisaje sucedáneo, un espacio de fuga donde perderse, para mitigar la realidad, incluso para intentar mitigar el dolor de las sucesivas penetraciones (en algún momento, la protagonista cuenta cómo ha dejado en pantalla la imagen de una mariposa aleteando para, concentrada en el aleteo, olvidar la invasión de otro cuerpo; un cuerpo, nótese, que puede ser también un cuerpo militar, identificable por su actitud: así, ella sabe reconocer la diferencia entre un policía y un detective). Su relación con otros cuerpos garantiza, con el intercambio económico, la alimentación propia y la sobrevivencia familiar:

El cierre abajo y el lulo en condiciones. Ahora solo tengo que clavarme. No debo rechazar al lulo de hombre, no quiero pensar en su humedad y menos en su condición elástica. No puedo rebatir la importancia de sus mil pesos en todo el contorno de mi cuerpo o en el transcurso de mi vida, pues su vaho influye hasta en el impulso mecánico de mi pierna cuando subo la escalera con la bolsa. La misma bolsa que llevo al cíber y que después lleno hasta la mitad con el pan que compro en el almacén. Un kilo no más porque ahora somos menos. (105) 
En medio del dolor y el abandono, del tráfico de sí misma para dar de comer a su familia, la vida transcurre como un simulacro. Es la puesta en escena de varios fingimientos: el placer fingido en el servicio sexual, la autoridad incierta del padre en la casa, el amor filial desmentido a menudo por las actitudes de la madre y la hermana, la masticación como ejercicio, se complementan con la entrada al mercado virtual, exploración de una realidad paralela también descoyuntada, también mentirosa. Y siempre el dinero, o su carencia, la pobreza. Contando la plata acumulada por sus servicios, dejando lo que gana en el alquiler de su cubículo en el cíber, recontando monedas para pagar su bocado del día, que comerá sentada en un banco en medio del desastre, la protagonista se integra a la corriente de circulación monetaria. Ahí otra opresión, otra ocupación inicua. La vida es apenas vivible en tales términos, pero la joven narradora ha decidido abstraerse de todo, caminar como autómata, a pesar de que, como muestra ese monólogo interminable que es la novela, piensa todo el tiempo. Su voz, esa voz que ocupa a su vez todo el espacio textual, también se ve ocupada, literalmente, por las interrupciones de una especie de reporte o registro de armas invasoras del espacio del bloque habitacional. La voz de la narración se ve invadida por una afirmación recurrente donde solo cambia el tipo de armamento. Un conteo compulsivo del armamento que parece aludir a la presencia efectiva de los policías de las Fuerzas Especiales a que alude el título de la novela; la certeza de la existencia multitudinaria de armas que, aun ocultas, amenazan. También pudiera tratarse de un mercado de armas (son cifras grandes), una exposición, una página web para venderlas, lo cual, aunque no se alude directamente, enlazaría la represión con la compulsión al consumo. Ambos gestos, el miedo y el consumo, perfilan la existencia de esa joven que vive y cuenta su entorno con la naturalidad de quien no aspira a cambiarlo, consciente incluso de la imposibilidad de huir. Luego el conteo permanente cobrará sentido. Un día, explica, los policías 
decidieron no vaciar los bloques. No los vacían porque es un operativo blando, inofensivo. ¿Cómo lo sabemos? Por los números de tanquetas, las balizas, las bombas de gas, los cascos, los garrotes, los gritos, los carros lanzaguas, el ritmo corporal que le imprimen a esta operación. Pero especialmente por los silbidos de advertencia que cruzan el cemento y que nos señalan el grado de intensidad del allanamiento. Había ochenta proyectiles de artillería de $280 \mathrm{~mm}$. ¿Quiénes silban? Los expertos del bloque. [...] Ellos silban la magnitud de la operación. (66-67)

El conteo clandestino, eterno, inunda el texto y, a su modo, interviene la vida de los personajes; podría ser también la banda sonora de una imagen, la de la vida cotidiana en los bloques; si la policía está casi siempre vigilante, "los expertos del bloque" también. Silbando ofrecen una guía para transitar ese espacio en perpetuo estado de sitio. La novela usa como epígrafe una frase de Severo Sarduy, una de las figuras tutelares, pudiera decirse (si no sonara algo ridículo en su caso) de Diamela: "Soy una Juana de Arco electrónica, actual”, dice la cita. El martirologio virtual, el sacrificio cíber, forma parte de la cotidianidad de la narración. La traducción cultural (esa referencia a Juana de Arco) equipara a la protagonista con una figura trascendente de la historia universal (es decir, de la historia europea), estableciendo así un paralelo risueño con una anécdota que relata la joven: había visto carteras y zapatos hechos de piel de lampalagua, una víbora argentina, baratísimos, intentando establecerse como mercancía; ahora ha visto los mismos productos anunciados desde Francia, en otro contexto, más dignos de la comercialización gananciosa. Algo similar refiere esa irónica cita de Sarduy. El contrapunto irónico entre el sacrificio real y el sacrificio virtual aparece desde los primeros trazos de la historia. El capítulo inicial, "El trabajo que tengo", explica:

Voy al cíber como mujer a buscar entre las pantallas mi comida. Todos se comen. Me comen a mí también, me bajan los calzones frente a las pantallas. O yo misma me bajo mis calzones en el cíber, me los bajo 
atravesada por el resplandor magnético de las computadoras. En cambio, el Omar o el Lucho solamente se lo sacan, más fácil, más limpio, más sano, provistos de la cómoda seguridad de que nada les resulte destructivo o verdaderamente insalvable. Pagamos trescientos pesos por ocupar media hora el cubículo. Me bajo media hora los calzones y dejo que me metan el lulo o los dedos adentro, hasta donde puedan. Nunca digo: sácame el lulo ni digo: sácame los dedos. No lo hago porque me concentro en el sitio ruso de modas alternativas que me absorbe tanto que mis ojos se pasean por mi cerebro clasificando las prendas de manera hipnótica. Después abandono corriendo el cíber y me voy a consumir todo lo que puedo. (11-12)

He aquí una clara representación del flujo económico. El cuerpo se vende, cobra, y gasta; se gasta, se repone. Pero también la condición femenina es un dato importante, una condición que conlleva el ahondamiento de la explotación: “Omar [...] es el mejor chupapico del cíber [...] Le pagan hasta cinco mil, eso asegura él [...]. A mí me pagan mil porque soy mujer" (12-13).

Y está el espacio. El cíber, claro (en algún momento la protagonista declama: "El cíber es todo para mí, milagroso, gentil" (14); pero también la calle, obstruida por la presencia policial, por el ir y venir de gente que, como autómatas, cumple su rutina minuciosa sin destacarse, metamorfoseándose con su entorno; por eso hay niños bloques y hasta perros bloques, "los quiltros bloques ladraban su temor" (94); "una turba bloque nos ovacionaba"; "los habitantes bloques se burlaban" (95). Y a los bloques debe parecerse una si no quiere ser atacada; con sus amigos, el Lucho y el Omar, dice, "juntos formamos tres bloques”. También se identifica del mismo modo con su madre y su hermana: "nos parecíamos como mujeres y sabíamos que ese exceso, esa grasa y esa precisa azúcar nos iba a proteger ante los pacos y los tiras pues nos volvíamos indistinguibles. Nos convenía ser un bloque. Mi padre no. Él tiene una figura distinta. Elocuente" (56). Ser bloque es arte de transfiguración y camuflaje; para integrarse al paisaje hay que dejarse ir de manera que policías y soldados, suficientes en artes de espionaje, auxiliados por la 
tecnología, no puedan establecer la individualidad, la soledad de un cuerpo específico, incluso de una historia personal propia. La narradora incluso se pregunta si tener idéntica fecha de nacimiento que sus amigos no proviene de la manipulación de los archivos, del seguimiento virtual con "programas de última generación". Carece, claro está, de una respuesta, pues no dispone más que de la información muchas veces banal de la red. Cada pregunta, cada hipótesis, concluye con una afirmación de ignorancia: "No lo sabemos". Ese abandono del saber, la incertidumbre alimentada con persecución y miedo, es su condición de vida. Como sobreviviente suele abandonarse a la virtualidad de los anuncios y las modas: "Tengo que olvidarme del bloque, de los niños, de los dientes, de los cascos. Tengo que olvidarme de mí misma para entregarme en cuerpo y alma a la transparencia que irradia la pantalla" (39).

Otra variante del abandono, de ese darse por vencida frente a la banalidad de la imagen renegando de la comunicación real, se resuelve frente a la queja dolorosa de la madre y la hermana. Cuando llega a ser insostenible, elige fotografiarlas para hacer su sufrimiento virtual, digno de figurar en cualquier sitio de reproducción infinita, de esos que abruman con tantas imágenes que impiden fijar alguna: "Mi hermana, sangrante, abrazada a mi mamá, pálidas las dos porque ellas siempre se han amado con un tipo de pasión escalofriante. Después yo me iba porque cuando descubrían el enmarque en el celular, se volvían en mi contra de una manera que me aterraba" (32). Incomprendida, su afición a enmarcar la realidad, a hacerla imagen, opera como recordatorio de que toda pose es falsa, de que el sufrimiento carece de autenticidad, mientras su adicción a la red la protege (no del todo; nunca se alivia del dolor por las sucesivas penetraciones de sus clientes) y le permite emanciparse momentáneamente de la opresiva realidad. El miedo, la desesperanza, la opresión vivida como un hábito también se afianzan en los cuerpos, son ellos los que podrán resistirse o no, hacerles frente al miedo y la desesperanza.

La familia, pensada como cuerpo simbólico, también ha sido mutilada. Golpes, cicatrices y costillas rotas se traducen en la ausencia de algunos de sus 
miembros. Los hermanos de la protagonista y los hijos de su hermana simplemente no están desde la primera de esas 48 horas de la vida en el ghetto infernal donde apenas puede una respirar, circular por el mismo camino cada día, venderse clandestinamente en el cíber, y a veces hasta servir sin recompensa. Cazada por la policía como ratas, la familia podría deshacerse a causa de unos: "Policías ociosos, enfermos de imágenes prohibidas [...], recalentados por la censura. [...], nos siguen por todas partes, nos estudian. Había cien mil bombas de neutrones U-238” (26). Y más adelante:

Yo me debo a mi familia que me queda. Me debo también a los que no podemos nombrar. Entiendo lo que el bloque experimenta y calla. Conozco lo que tenemos guardado detrás de las rejas. Sé cómo esquivar la arremetida profesional de los pacos y los mordiscos de los perros que estilan sus babas. Había cuatro mil pistolas Kjw Saber P 226 Full Metal.

Sabe que los policías son también víctimas, pero no los disculpa; son quienes le impiden vivir en paz: "los carabineros llegaron repartiendo lumazos justo el día en que estaban recién pagados. [...] Mi papá se quedó sin respiración, no sé si las costillas se le enterraron en el pulmón. [...], mientras el Lucho que estaba abriendo el cíber cayó en la puerta como un mártir" (50).

Al final, sin embargo, todo se concentra en la circulación del dinero. Una paga insuficiente, la cancelación del goce, deviene impulso global hacia la violencia. Mantener a la gente a raya, esquilmarlos, también es parte del trabajo de la policía, su modus vivendi. La protagonista quizás sea la única capaz de resistir. Aún no ha sido quebrada por los golpes, aunque su cuerpo haya sido invadido una y otra vez. Su espacio constreñido a una práctica pública irrisoria, la de escuchar música o navegar por la red, se reduce al bloque. El miedo lo inunda todo. La desconfianza va ocupando espacio en sus relaciones con la familia, y la ignorancia. No en balde cada pregunta recibe la misma respuesta: "no lo sabemos". Una 
ignorancia expresión del miedo, no ya a la muerte o los abusos, sino a la total disolución del yo.

Hay otra amenaza, la del desahucio virtual. Cierta vez, apagadas las antenas de los celulares, los pobladores de los bloques andaban desorientados, inmersos en "un estado de estupor" que los aliena por ausencia. En tal terrible acumulación de catástrofes, sin embargo, la joven puede renunciar al miedo y ajustarse minuciosamente a esa existencia intervenida, como cuando describe "Un lunes perfecto":

[...] hoy es un lunes pacífico para mí, un lunes que no va a dar origen a una situación fatal ni menos van a entrar los pacos a culatazos al departamento, con sus terribles cascos, los chalecos antibalas, las botas, los guantes, mientras mi madre $[. .$.$] se hinca ante los pacos, se hinca como una feligresa$ ante los pacos y les pide que no se los lleven, que por favorcito los dejen, qué les cuesta, qué les cuesta, déjenmelos, a mis hijos, son míos, de nosotros, de la familia, ¿entienden?, [...] pero yo no puedo hincarme, no puedo hincarme [...] Nadie se hincó. Quisieron hincarse. Fui yo la que se fue desplomando, desplomando por el miedo y la eficaz imagen de la sangre hasta quedar hincada delante de los pacos. Pero hoy es otro lunes, este lunes tranquilo, helado y tranquilo [...] (81-82)

Presa del miedo cotidiano, sus clientes son todos miembros de esas fuerzas de ocupación que, además de su espacio vital ocupan su cuerpo en las sesiones del cíber. Cuando la navegación virtual va perdiendo potencia la alienación deja poco a poco de ser posible. La penetración de la realidad es cada vez más difícil de eludir cuando terminan por cortarles lo único que podía hacerlos más o menos felices, más capaces de sobrevivir. Una vez desconectadas las antenas, los celulares sin tono, muerto el padre, el cíber casi en ruinas, tiene lugar "el operativo más escandaloso en la historia de los bloques" (147-148). Mientras revisa la naturaleza de cada uno de sus amigos, la protagonista asegura: "yo soy totalmente bloque y 
voy a terminar fundida al cemento o convertida en un ladrillo de mala calidad o me consumiré en un ladrillo anémico con la columna doblada sobre mis débiles patas" (149-150). Juntos permanecen atrincherados en el cíber, lidiando con la soledad y la incertidumbre: "Tenemos hambre y nostalgia, hambre y miedo, hambre y temor [...] pero todavía nos queda una forma curiosa de odio profundo, incisivo, sin el menor atisbo de remordimiento" (151).

Intentando dejar atrás "unos estériles años bloques familiares que solo arrojaron un montón de pérdidas" (160), su madre y su hermana se van. Ella se queda ¿resistiendo?, en "Los símiles de edificios que tenemos”, con sus pasillos "cárceles en los que no nos amotinaremos jamás". Su destino es inescrutable, incierto, aunque sospecha que, como tantos otros habitantes del bloque, terminará en "una fosa común o alguien regalará mis huesos para un experimento. Lo vi en un sitio. O venderá mis huesos como si fueran restos chinos que se van a comerciar por Internet. Me convertiré en un adorno de sobremesa para una casa australiana" (161).

La idea de la muerte, de la total aniquilación (y la conversión en mercancía de sus restos), logra conjurarse cuando los policías restauran las antenas de los celulares. En el apocalíptico final, la invasión del espacio bloque se narra sin evasivas (y sin posibilidad de evasión): "Los pacos y los tiras se vienen con todo. Es parte de nuestra vida. [...] Pero entiendo con un optimismo demente que tenemos otra oportunidad" (163). Ahí desaparece la voz narradora, que hasta entonces nos fuera llevando por el paisaje bloque, develando sus personajes, su ritmo. Parece haber terminado el sufrimiento. Pero no, la historia no concluye, queda aún un mínimo fragmento, una intervención última de la protagonista que no por azar se registra en un último capítulo titulado "Juego de futuro":

Había doscientas mil armas de sensores fusionadas CBU-97.

Estamos parapetados en el cíber. Ya nos digitalizamos.

Navegamos el cubículo para probar el primer video juego chileno. Un veloz juego de defensa diseñado por el Lucho, musicalizado por el Omar 
y perfeccionado por mí. Movemos el cursor con maestría. Empieza el juego. $\mathrm{Y}$ entonces aparecemos en la pantalla con el título que diseñamos: "Pakos Kuliaos"

Había cuatro mil millones de proyectiles de artillería teledirigidos de alto rango XM82 Excalibur. (165)

La circulación de las armas, del dinero, de los humores corporales, del deseo, el hambre o el dolor, ha venido armando para nosotros un paisaje susceptible de verse habitado. Es el paisaje del presente. Un presente ocupado por la policía, la pobreza, el terror, donde apenas es posible una sobrevivencia nimia, minúscula, intrascendente. Hasta el final, todo transcurre dentro de la realidad. Pero (y esto explicaría la idea del martirio y de la guerra virtuales, sugerida por la cita de Sarduy) esta coda revienta la historia, la sumisión, la existencia en ciclos iguales gobernados por el temor y el dolor de un cuerpo que resiste a duras penas, que se vende y encaja sus heridas como experiencia cotidiana. Hay otro espacio. El espacio digital, la virtualidad de la red, hasta entonces solo presente como ensoñación, como espacio de evasión, como ilusión engañosa de una realidad digna de rechazo. Ahora, una vez que se han digitalizado, los jóvenes emprenden la lucha. En el título del juego virtual está la clave del relato previo: "Pacos culiaos" es el grito de guerra de los jóvenes estudiantes chilenos que exigen en las calles una educación pública, gratuita y de calidad. Su manifiesta repulsa frente a la represión policial.

Los protagonistas de Fuerzas especiales vegetan, completamente empobrecidos no solo económica sino también espiritualmente. No tienen espacio para pensar, si acaso para enervarse viendo desfiles de modas tan exclusivas como falsas, o para descargar la música que les permita lidiar con el ruido ambiente. El circuito de circulación es mínimo, del cíber al bloque y del bloque al cíber; mínima también la posibilidad de intervención en un espacio completamente ocupado y dominado por la policía y el ejército. La asunción de ese grito de guerra en el terreno virtual donde se han visto impelidos a recluirse, rescata la voz de la resistencia estudiantil y juvenil, con su extraña sensación de "optimismo demente" que salva 
a la protagonista de su anulación total. Ya no terminará como adorno de mesa en una casa australiana, ahora ha reencarnado en los jóvenes que día a día combaten la represión e intentan programar algo distinto y mejor para la gente de su generación.

A diferencia de aquella antigua fábula china donde un pintor conseguía una representación insólitamente exacta de la realidad y terminaba perdiéndose en su cuadro para evadirse; estos jóvenes se internan en el mundo de los juegos virtuales para acercarse a la realidad. En un paisaje donde todo es ruina, donde la labor de desgaste de las fuerzas policiales ha ido acabando con la vida, ese grito de guerra, que los conecta con las grandes manifestaciones juveniles del presente chileno, no clausura la realidad; allí la guerra no ha terminado, está apenas comenzando.

Sumar (2018), la obra más reciente de Eltit, articula una suerte de condensación de temas abordados previamente por ella. Allí un grupo de vendedores ambulantes marcha hacia la moneda. En esta simple descripción hay un espacio de sentido donde cavar: la moneda es la representación del dinero; pero es también, claro está, el nombre del palacio de gobierno de Chile. Si ahondáramos en la ansiedad que reúne a los marchistas podríamos pensar no solo en términos de llana economía: estos desposeídos no pretenden únicamente acceder al dinero, a vías de economía formal de la cual han sido desplazados, sino a La Moneda, al poder público que, en tanto representantes del pueblo chileno, les fuera arrebatado por el golpe del 11 de septiembre de 1973. Cuando se lee a Eltit es muy difícil una interpretación reacia a reconocer el peso del trauma político del golpe, de su profunda huella en el país actual. Una interpretación que podría ramificarse infinitamente, y hasta negarse, si no abriera la novela la sobrecogedora apelación del padre de una de las víctimas. Fechada el 15 de octubre de 1973 y proveniente de la compilación de Cartas de petición 1973-1989, de Leonidas Morales, es la carta del padre de una joven apresada y asesinada que pide recuperar el cadáver de 
su hija. La víctima fue "arrestada en la industria Sumar" (9) y quizás esa sea una de las señales de por qué la autora eligió ese título para su novela. Un título, por demás, coherente con la idea de una marcha, que pretende sumar continuamente simpatizantes para aumentar su capacidad de interpelar a las autoridades. Cabría, quizás, una reflexión sobre el modo especular en que se dirimen las demandas: durante la dictadura, de modo individual, por escrito; en el Chile actual, colectivamente, en las calles, compartiendo un megáfono para expresar de viva voz la solicitud. Pero este documento es solo un marco, un portón de entrada que opera por contraste como contrapunto de la actualidad de la anécdota. A una voz única, las voces colectivas; a la demanda de un cadáver, la demanda por la vida, por recuperar un espacio en la economía formal, del que los marchistas han sido desplazados (son jubilados, desempleados, inmigrantes, marginales siempre en una economía cuyo perpetuo crecimiento se traza también en la exclusión de grandes sectores poblacionales). Aquel conflicto, en otras dimensiones, sostiene la anécdota de Sumar. Ahora lo que se quiere recuperar no es un cuerpo; es el acceso al consumo. La marcha busca llegar a la moneda y el relato registra, a su paso, los cambios tecnológicos, las necesidades generacionales, los disensos internos. Todo lo que hace de ella un acto en presente. La voz de Aurora Rojas domina el discurso. Pero es una voz lateral, no lidera la marcha, tan lateral es que tiene una doble: su tocaya. Así, la experiencia de la misma mujer se cuenta de dos modos, se discute, se cuestiona a sí misma. La marcha avanza bajo la vigilancia de la nube, drones, satélites y robots; el espacio ya ha sido ocupado, vendido, y hasta los aviones deben pagar por seguir su curso. A ras de suelo, avanzan trabajosamente los ambulantes. En ese paisaje transcurre la historia; un paisaje ampliado hacia el pasado no solo por la cita inicial, sino por noticias de los más variopintos personajes históricos que al asomar en las conversaciones de los ambulantes contribuyen a dotarlos de una genealogía, o quizás esas presencias sean solo un reflejo de la trivialidad de la información, de cómo circulan las historias más increíbles o prescindibles o necesarias, todas disponibles por igual. La duplicación no ocurre solo hacia el exterior del cuerpo: Aurora Rojas puede ser también, como ella misma dice, "una 
máquina de sueños", garante de un futuro siempre incógnito. Sus visiones casi siempre apocalípticas refieren volcanes en erupción, maremotos, tragedias colectivas, pero justo antes de empezar la marcha, soñaba escuchar marchas de combate, de esas que "todavía sostienen la tozudez enfermiza de la esperanza" (17). ¿Cómo interpretar el abigarramiento de señales, las pistas múltiples que afloran en el discurso de Aurora Rojas? El intrincado manojo de referencias a lo histórico y lo biológico, al presente y al pasado, a la circulación y las dolencias más peregrinas de un cuerpo humano o social, individual o colectivo, conforman una percepción difusa por momentos, otros más centrada, de la vivencia del conflicto central, la inaccesibilidad de la moneda. Imaginativa cronista de la sociedad contemporánea, Eltit repite aquí la apelación a lo biológico, a los síntomas y desajustes corporales como testimonio de una situación social específica. Por eso a menudo nos planteamos la novela como un enigma, intentando leer entre líneas, pescar alusiones, otorgar sentido a la referencia más estrambótica, como cuando leemos sobre un barco asesino en el océano atlántico y aparece la OTAN como una referencia enmascarada. Quizás estemos politizando en exceso nuestra lectura, pero la intención referencial tiene raíces en la propia novela, en la cual una afirmación aparentemente banal conduce a pensar el destino humano en tiempos de continua sangría planetaria en los escenarios del petróleo, las guerras o el turismo depredador. La marcha tiene un sentido claro: "estamos absolutamente cansados de experimentar toneladas de privaciones. Hastiados de los golpes que nos propinan las oleadas de desconsideración y de desprecio" (8).

Quienes marchan en busca de la moneda quieren vivir, recuperar derechos, dejar de ser esclavos, siempre marginales en las vías de circulación del dinero, llegar al centro (La Moneda) y ejercer sus cuerpos en el espacio público sin acotamientos o prohibiciones. Conquistar un espacio que fue suyo y les ha sido expropiado. El habla metafórica de Diamela Eltit conjuga tales denuncias de profundo sentido político con un tono pretendidamente banal, monótono, como una larga confesión voluntaria de ese personaje que lleva el nombre que tuvo la esperanza. Los incesantes desvíos y múltiples señales de disloque (en contraste con 
el sentido unidireccional de la marcha) recuerdan una vez más las obsesiones y hasta el lenguaje coloquial finamente urdido como palabra popular tan presentes en la poética de Sarduy, tanto como la duplicación de las Auroras Rojas o el humor soterrado en afirmaciones pretensiosamente elaboradas y plenas de connotaciones: "la ilegalidad que nos han adjudicado", "la extensa injusticia de los alimentos", cierta "raigambre arrocera", "el hábito numérico con el que se certifica el estado calamitoso del mundo", por ejemplo (20-22). Tales señales invitan al desciframiento, desperezan una sonrisa o nos llevan a admirar la acumulación de creatividad e ironía con que han sido plasmadas. La escritura de Eltit es siempre un desafío.

La protagonista es una mujer que, así como la parlanchina hija de Impuesto a la carne llevaba a su madre alojada en su interior, carga con sus cuatro hijos nonatos en la cabeza. Hay que reconocer cuánto detona este tipo de imágenes. ${ }^{7}$ Cuánto nos impulsa a pensar en su sentido. Es un modo antiguo, pasado de moda, predecible quizás, pero sigue siendo para mí el mejor modo de enfrentar una escritura que busca todo el tiempo desbalancear lo previsible, llevar a escena la experiencia vital más urgente de la contemporaneidad; forzarnos a inquirir por el propio lugar de nuestro cuerpo en esos problemáticos paisajes irreales donde, sin embargo, identificamos sin esfuerzo las marcas del presente y de la historia. Como comenta en algún momento el personaje: son recuerdos, deseos, convicciones "que todavía no están dispuestos a rendirse ni al olvido o a la constante y rutinaria resignación a la que obligan los días, ni menos a las fantasías que provocan las monedas enceguecedoras" (22-23).

La precariedad laboral de los vendedores ambulantes se potencia no solo en lo contado, sino en la elección del léxico, así se habla de "estigma", "rostros demacrados", "incertidumbre", "imprevisible", “zozobra”, "angustia",

${ }^{7}$ En su presentación de la novela, Julio Ramos — a quien agradezco el envío de sus palabrasindicaba cómo "se sugiere que los nonatos que la narradora porta en su cerebro son los custodios o archiveros del secreto, el arresto y desaparición de la obrera textil en la fábrica Sumar, lo que nos recuerda también que la suma, la asamblea o el agregado político, está siempre transitada por la huella de una resta, el excedente radical de Diamela Eltit", en una demostración de la ductilidad interpretativa de esas imágenes cifradas tan frecuentes en la narrativa de esta autora. 
“estupefacción”, etc. Todo junto. Y la expropiación de lo público toma cuerpo en el proyecto de aceras patrocinado por un inversionista finés: reducida a objeto de vitrina, la vida misma resultará imposible. La huella de otros libros y otros personajes está en Sumar, sumando en sí voces y modos previos en la narrativa de Eltit. Cuando los ambulantes confiesan, a propósito de algo: "no lo sabemos" están citando la perplejidad cotidiana de los personajes de Fuerzas especiales (28). Como la madre que carga sus hijos en la cabeza, convive con sus opiniones y gestiona su convivencia, la autora Diamela Eltit carga consigo sus libros previos, voces antes imaginadas que de vez en cuando encuentran el modo de aflorar. Al mismo tiempo, su más reciente novela explora la relación entre la realidad y el mundo virtual en la era digital, lo desajustado o incoherente que puede parecer una vida cotidiana de carencias múltiples en plena convivencia con tecnologías de comunicación o vigilancia ampliada y la pobreza como naturaleza, vista su perdurabilidad para ciertas gentes.

Aurora Rojas tiene varias obsesiones, y la moneda es la más recurrente; pero también su peculiar forma de maternidad, la organización de la marcha; el testimonio corporal de una vida de trabajo, el liderazgo de Casimiro Barrios, las múltiples solicitudes de dinero. Es una observadora y una testimoniante, pues también da cuenta del entorno que, a su modo, la marcha contiene: "un puñado selecto del mundo se ha coludido en un proceso no demasiado sutil, destinado a destruir a cada uno de sus excedentes, como a nosotros, los ambulantes" (52). El transcurso de la marcha en su realidad y su posibilidad, plena de citas de sucesos previos, de remisiones inesperadas, vive en el discurso de Aurora Rojas como reivindicación de la memoria colectiva de los expulsados de la economía de la inversión y la ganancia; los desplazados por el neoliberalismo. Pero sus palabras no solo refieren al ámbito económico, es una palabra sumamente política, hablada en lengua popular y a menudo elusiva, dispersa en los meandros de una peroración interminable que, sin embargo, podría identificarse con una suerte de conciencia de la marcha y cuyo objetivo sumo sería "impedir la extensión viral de la indiferencia" (54). Por eso no sorprenden tantas alusiones a tragedias provocadas por la 
expoliación de los bienes comunes, pesadillas de expulsión del espacio público, etc. Imagino cuantas sorpresas similares pueden hallarse en el magma creciente del pensamiento de la protagonista; para los lectores habituales de Diamela, los acertijos son moneda común; aquí, sin embargo, se acumulan datos disponibles en la red, accesibles, pero a menudo ignorados por la gran prensa. Hay un par de menciones concernientes a Cuba: la referente a los presos de Guantánamo, al parecer olvidados para siempre tras el fracaso de Barack Obama de cerrar la cárcel que Estados Unidos mantiene en territorio usurpado a Cuba, y el caso de Ana Belén Montes, analista militar que declaró haber espiado para el gobierno cubano por razones éticas, condenada a 25 años de cárcel — “de manera radical e irreversible y hasta inhumana" (133) - En medio de la multitud de señales y la apariencia caótica del parloteo de la protagonista, ocupada también en mantener cohesionado al colectivo de marchistas, entusiasmado a su líder, calmos a sus hijos nonatos y contenidos los asaltos de sus propios órganos frente al abuso que supone el desmedido tránsito sin fin, menciones como esas recuperan el escenario global en que tienen lugar tales tipos de marchas multitudinarias, tanto como la referencia a los drones y su uso actual: "Dice que han cometido crímenes muy rotundos que escandalizan levemente a los promotores de las buenas costumbres" (76). Hasta cierto punto, la novela es ella misma una insurrección, como la eterna marcha que relata, una marcha compuesta por "cuerpos públicos. Expuestos" que, al mismo tiempo, son representación de grandes colectivos humanos, de sueños y proyectos multitudinarios, de expectativas incumplidas, pero no desechadas (una interpretación posible de la presencia de los cuatro nonatos) y que constituyen "un cúmulo de cuerpos enojados por el lugar terminal" que la narradora concienzudamente alude una y otra vez, "Pa que no se me olvide" (98). ${ }^{8}$

${ }^{8}$ Una afirmación que parece confirmar la existencia de los hijos nonatos de Aurora Rojas como la memoria posible de rebeliones previas ("Adictos a la memoria, envueltos en un descontento crónico", p. 109). La memoria es uno de los temas fundamentales de la novela: los marchistas son "cuerpos de colección", "un derruido recuerdo", "archivos del fracaso" (115). A propósito de la homeopatía se alude a cómo "quizás el agua tenía memoria" (158), sospecha que podría devenir acusación, como ocurría en El botón de nácar (2017) de Patricio Guzmán. 
La moneda, verdadera protagonista de esta historia, es el síntoma de los tiempos que corren. Del tiempo histórico marchado por la toma de La Moneda por los militares sublevados en 1973 hasta la exaltación del mercado y la circulación del dinero por la política económica impuesta por el neoliberalismo actual.

No debe escaparse la relación entre el poder y el dinero. La comprobación de que, una vez negado el acceso popular a La Moneda, también la moneda proveedora de satisfacciones materiales parece inalcanzable. En la necesidad expuesta como objetivo de la marcha— de "tomar la moneda" parece resonar aquel mensaje de los golpistas: "Misión cumplida. Moneda tomada. Presidente muerto".9 Por eso esta novela es legible no solo en términos de actualidad, sino históricos, lo mismo que debe leerse "con acento chileno", una insistencia aparentemente banal que conlleva otra conexión con su contexto.

Se trata también, claro está, de un palimpsesto donde conviven señales dispares provocadoras de interpretaciones disímiles (niveles de lengua, referencias históricas, cultura popular, ironía, temas de actualidad como la migración o el consumo cultural y tecnológico, la vigilancia y la represión, etc.) que articulan una crónica posible, irrisoria e indignada, de la vida contemporánea, como explica Casimiro Barrios a las tocayas, el presente es:

Un siglo nuevo, el que nos tocaba vivir, este siglo XXI, dijo, realista, pragmático, tanto que ya había emprendido el proceso de destrucción de todas las vidas que no resultaran proclives a resignarse o inclinarse ante la moneda o a llorar, a implorar y revolcarse frente a la posibilidad de contar con una montaña de monedas. (102-103)

Por eso la marcha de vendedores ambulantes y desplazados de un orden económico excluyente, avasallador, pretende cambiar las cosas. Con su desacato a

\footnotetext{
${ }^{9}$ En otro momento refiere "la ambición que desataba el poder de la moneda, los pasillos, la Alameda vislumbrada desde los ventanales. Los techos destrozados. Los árboles", en clara alusión al palacio de gobierno (146).
} 
las formas de veneración de y subyugación por la moneda y con la instalación de otra clase de circulación (monetaria y espacial), una que se esfuerza por conseguir la abolición de la injusticia.

\section{Bibliografía}

Brito, Eugenia. Campos minados. (Literatura post-Golpe en Chile). Santiago de Chile: Cuarto Propio, 1994. Print.

Eltit, Diamela. El cuarto mundo. Santiago de Chile: Planeta, 1988. Print. . El padre mío. Santiago de Chile: Francisco Zegers, 1989. Print. . Fuerzas especiales. Santiago de Chile: Seix Barral, 2013. Print. . Impuesto a la carne. Santiago de Chile: Seix Barral, 2010. Print. . Jamás el fuego nunca. Santiago de Chile: Seix Barral, 2007. Print. . "Los bordes de la letra." Casa de las Américas XLIII.230 (enero-marzo 2003): 108-12. Print.

. "Los bordes de la letra." Casa de las Américas enero-marzo.230 (2003): 109-12. Print. . Los trabajadores de la muerte. Santiago de Chile: Seix Barral, 1998. Print. . Los vigilantes. Santiago de Chile: Editorial Sudamericana, 1994. Print. . Mano de obra. Santiago de Chile: Seix Barral, 2002. Print. . Signos vitales. Escritos sobre literatura, arte y política. Santiago de Chile: Ediciones Universidad Diego Portales, 2008. Print. . Sumar. Santiago de Chile: Planeta chilena, 2018. Print. . Vaca sagrada. Buenos Aires: Planeta, 1991. Print.

Eltit, Diamela, and Leonidas Morales T. Emergencias: escritos sobre literatura, arte y política. 1. ed. Santiago de Chile: Planeta/Ariel, 2000. Print. 
Eltit, Diamela, Paz Errázuriz. El Infarto del alma. $1^{\circ}$ edición 1994 ed. Santiago de Chile, Chile: Ocho Libros, 2010. Print.

Klein, Eva. "La (auto)representación en ruinas: Lumpérica, de Diamela Eltit." Casa de las Américas enero-marzo.230 (2003): 130-35. Print.

Lagos, María Inés, ed. Creación y resistencia: La narrativa de Diamela Eltit, 1983-1998. Santiago de Chile: Cuarto Propio, 2000. Print.

Lorenzano, Sandra. "'El cuarto mundo"." Tres novelas. Ed. Eltit, Diamela. México: Fonde de Cultura Económica, 2004. Print.

Morales, Leonidas. Conversaciones con Diamela Eltit. Santiago de Chile: Cuarto Propio, 1998. Print.

Neustadt, Robert. CADA día: La creación de un arte social. $2^{\circ}$ ed. Santiago de Chile: Cuarto Propio, 2012. Print.

Olea, Raquel. "El cuerpo-mujer. Un recorrido de lectura en la narrativa de Diamela Eltit." Una poética de literatura menor: la narrativa de Diamela Eltit. Ed. Lértora, Juan Carlos. Santiago de Chile: Cuarto Propio, 1993. Print.

Ramos, Julio. "Sumar de Diamela Eltit: el excedente radical de la ficción." Mímesis abril 10, 2019. Web.

Richard, Nelly. "Tres funciones de la escritura: deconstrucción, simulación, hibridación." Un poética de literatura menor: la narrativa de Diamela Eltit. Ed. Lértora, Juan Carlos. Santiago de Chile: Cuarto Propio, 1993. 37-51. Print. 